\title{
Currency Substitution: A Test of Its Importance
}

\author{
Dallas S. Batten and R. W. Hafer
}

A that they insulate the domestic economy and money supply from foreign monetary disturbances. "This view has been challenged by a number of critics who question the assumption behind the monetary independence argument that domestic and foreign currencies are not considered subsitutes in demand by domestic residents. ${ }^{2}$ A rational holder of money balances, these critics argue, would seek to diversify his portfolio of currencies for the same reasons that investors typicaly hold diversified portfolios of interest-earning assets. If currency substitution exists, domestic money demand should be sensitive to changes in both domestic and foreign influences. Consequently, even with flexible exchange rates, the existence of currency substitution exposes the domestic economy to monetary shocks from both home and abroad.

The purpose of this article is to assess empirically the importance of currency substitution in five major industrial countries by examining the significance of changes in the opportunity costs of holding foreigncumency-denominated money balances on the demand for domestic money. If currency substitution exists, changes in the opportunity costs of holding foreign money balances should generate a reallocation of money holdings and, consequently, influence domestic money demand. The evidence presented here $_{f}$ however, indicates that the impact of changes in

Dallas S. Batten and A. W. Hafer are senior economists at the Federal Reserve Bank of St. Louis. Sarah $R$. Driver provided research assistance.

The case for flexible exchange rates is made forcefully in Friedman (1953). In this ariatysts, we ignore the possibitty that monetary disturbances in a fiexible exchange rate world may have real consequences as goods prices change more slowly than do exchange rates. For a discussion of this, see Dornbusch (1976).

2For a discussion of these arguments, known collectively as currency substitution, see, anong others, Miles (1978a, b), Boyer (1978) and Mckinnon (1982). Alternative viewpoints are presented in Chrystal (1977) and Spineli (1983). the opportunity cost of holding foreign money balances on domestic money demand is statistically insignificant for almost every country analyzed. Thus, it does not appear that currency substitution jeopardizes the insular properties of a flexible exchange rate system. ${ }^{3}$

\section{EXCHANGE RATE SYSTEMS AND MONETARY INDEPENDENCE}

Under the Bretton Woods system of fixed exchange rates, each monetary authority was obligated to maintain the foreign exchange value of its currency within a specified range by intervening directly in the foreign exchange market. When the foreign exchange value of its currency rose to the upper bound of this range, the monetary authority sold its currency for foreign exchange in the foreign exchange market. This action increased the supply of "home" currency relative to its demand and lowered its foreign exchange value. The monetary authority continued increasing the supply of currency until its value decined. If the foreign exchange value of its currency fell to the bottom of the permissible range, the central bank would purchase its own currency with its foreign exchange reserves, thereby increasing its own currency's value in the foreign exchange market.

\section{No Monetary Independence Under Fixed Exchange Rates}

The obligation to maintain its currency's foreign exchange value reduces the domestic monetary author-

\footnotetext{
"It should be noted that, even under a flexible exchange rate regime, monetary independence may be lessened by the existence of international capital mobility. For a discussion of the effects of capital mobility on the insular properties of flexible exchange rates, see Tower and Willett (1976). it also should be noted that central banks' attempts to maintain a desired exchange rate by intervention may thwart the advantages of a flexible rate system.
} 
ity's ability to conduct a policy independent of those conducted by other countries. 'To see this, first assume that the domestic and foreign economies initially are in equilibrium. If the domestic monetary authority increases its money supply, the immediate result will be an excess domestic supply of money. Consequently, domestic residents will attempt to reduce their excess holdings of money by purchasing more goods, services and securities, both domestic and foreign. Such actions impart upward pressure on the general level of domestic prices and, concurrently, dowmand ptessure on the foreign exchange value of the domestic currency.

Since the monetary authority is obligated to defend its currency's foreign exchange value under a fixed exchange rate system, the resultant downward pressure on the exchange value requires it to purchase its own currency in the foreign exchange market with foreign currency. Obviously, this operation results in a decrease in the domestic money supply, reversing the initial expansion. In other words, having to maintain its exchange rate precludes the domestic monetary authority from independently changing its own money supply.

It is also the case that monetary shocks can be transmitted from one economy to another. Consider, for example, the impact of an increase in the money supply of country A on country $B$ in a two-country world of fixed exchange rates. As described above, the initial excess supply of money in A causes the exchange value of A's currency to fall relative to $B$ 's. When $A$ 's monetary authority intervenes, it buys its own currency, using its holdings of B's currency to pay for the transaction. Consequently, B's money supply must rise as B sells its holdings of country A's currency for more of its own. This, in turn, generates an excess supply of money in country $B$. Thus, the original monetary expansion in $A$ has been transmitted to $B$ because each country is obligated to maintain exchange rates within a prescribed range.

\section{Monetary Independence Under Flexible Exchange Rafes}

Under a system of flexible exchange rates, however, this inability to control the domestic money supply

\footnotetext{
${ }^{4}$ For a more detalled discussion of exchange rate movements, centra: banks' exchange rate objectives and their impact on domestic monetary policy, see Batten and ott $(1983,1984)$.
}

need not exist. With no obligation to maintain its exchange rate, the monetary authority can increase its domestic money supply and allow the exchange rate to fall. A system of flexible exchange rates also ptovides an environment in which monetary disturbances need not be transmitted from economy to economy; the exchange rate simply fluctuates freely in response to relative movements in money supplies. Thus, as long as the monetary authority is willing to let the exchange rate move as the market dictates, it can follow any domestic monetary policy that it desires.

\section{What If Currency Substifution Exists?}

The currency substitution argument suggests that this analysis mistakenly ignores the possibility that foreign currency is a substitute in demand for domestic currency. 5 That is, residents demand both domestic and foreign currencies. Advocates of this argument point to certain evidence of the existence of currency substitution. For example, multinationals, among others, hold various currencies simultaneously in order to reduce the costs of foreign transactions and to provide certain risk-decreasing benefits typically associated with asset diversification. ${ }^{7}$ As Miles has noted recently,

significant currency substitution does not require every little old lady on Main Street to hold foreign money. Al that is required is a significant subset of individuals and enterprises which on the margin are indifferent between holding another dollar of their money portfolio in domestic versus foreign money."

\footnotetext{
${ }^{5}$ See, for example, McKinnon.

"Our analysis focuses only on "onshore" substitution, that is, the substitution of foreign for domestic money balances by domestic agents. A second type, which we do not address directly, is "offshore" substitution - the substitution of one foreign "currencydenominated asset for another by domestic agents. Chrystal, and Chrystal, Wilson and Quinn (1983) analyze this second type and find significant offshore currency substitution. Most of this substitution involves interest-earning assets; consequently, its primary impact is on interest rates. Since we analyze onshore substitution within the framework of money demand (see below), whatever indirect impact offshore substitution may have should be captured by the inclusion of the domestic interest rate in equation 1 . (See discussion on p. 8.)

${ }^{7}$ Miles (1978a) has argued this. One may question the transactions motive as a significant reason for holding foreign currencies in a non-interest-earning form, especially since many highly liquid, interest-eaming assets are avallable in the Eurocurrency market. An argument may be made for holding these balances for speculative purposes, however; nonetheless, given the availability and easy access to the Eurocurrency market, one may discount the currency substitution argument on a priori grounds alone.

${ }^{8}$ Miles (1984), p. 1203.
} 
The mere holding of a diversified portfolio of currencies, however, is not sufficient for currency substitution to be meaningful. These holdings must also change in response to changes in the relative opportunity costs of holding foreign money balances. That is, if individuals actually hold a diversified portfolio of cur rencies, then they will respond to changes in the cost of holding one currency relative to another by changing the relative amount of each currency held. This readjustment of currency holdings that is, currency substitution enables monetary shocks to be transmitted (via money demand) from one economy to another even in a world of flexible exchange rates.

'To illustrate this possibility, assume that country B's monetary authority strives to maintain a targeted growth path for a narrow, transactions-oriented, monetary aggregate. In a world of currency substitution, residents in both countries hold both B's currency and A's currency. Now suppose that country A's monetary authority increases its domestic money supply while B's money supply remains unchanged. Immediately, money holders (individuals and firms) expect A's currency to depreciate relative to B's. With a flexible exchange rate system in effect, the central banks do not intervene to maintain the prevailing exchange rate. The expected depreciation of A's currency increases the opportunity cost of holding it relative to B's currency. Consequently, residents of both countries will desire to hold less of A's currency and relatively more of B's; that is, both the domestic and the foreign demand for B's currency will increase because of a change in country A's monetary policy. Thus, failure by policymakers in $B$ to recognize the external effects on domestic money demand may lead to inappropriate policy actions. As Mckinnon argues, ". . currency substitution destabilizes the demand for indi" vidual national monies so that one can't make much sense out of year-to-year changes in purely national monetary aggregates...."9

For another illustration of how currency substitution may affect domestic policy actions, assume that the domestic monetary authority in country $B$ is attempting to peg some domestic interest rate. As before, assume that country A unilaterally expands the growth of its money stock. This again produces an expected depreciation of A's currency relative to $B$ 's and, for a given level of income and interest rates,

${ }^{9}$ McKinnon, p. 320 increases the domestic and foreign demand for B's currency. For a fixed (in the short run) supply of money, the increase in B's money demand leads to an increase in market interest rates. Since the assumed policy of the monetary authority in country $B$ is to peg a domestic interest rate, it must offset this increase in rates by increasing its money supply. Thus, the policy action taken by country $A$ leads to a similar action by country $B$ if there is currency substitution and if the monetary authority attempts to target on a market interest rate.

In summary, the most important problem with currency substitution is that it may destabilize the domes. tic demand for money, thus hobbling a monetary authority's attempt to determine policy independent of foreign influences. Consequently, the impact of any particular monetary policy stance on the domestic economy may not be the desired one even in a world of flexible exchange rates.

\section{THE EMPIRICAL SIGNIFICANCE OF CURRENCY SUBSTITUTHON}

That currency substitution may exist and that it may reduce the insulating properties of flexible exchange rates are not sufficient reasons to conclude that it significantly lessens the degree of monetary independence among countries under a flexible exchange rate regime. Whether currency substitution is sizable enough to have the impact described above is an empirical issue.

\section{The Test}

A commonly used procedure to test for the importance of currency substitution is to estimate a domestic demand for money equation and determine if changes in the opportunity cost of holding a foreign currency significantly influence holdings of domestic real money balances. More formally, the following equation is estimated:

(1) $\begin{aligned} \ln (\mathrm{M} / \mathrm{P})_{\mathrm{t}}= & \alpha_{0}+\beta_{1} \ln \mathrm{y}_{\mathrm{t}}+\beta_{2} \mathrm{R}_{\mathrm{t}}+\beta_{3} \hat{\mathrm{F}}_{\mathrm{t}} \\ & +\beta_{3} \ln (\mathrm{M} / \mathrm{P})_{1-1}+\varepsilon_{\mathrm{t}}\end{aligned}$

where $\mathrm{M}=$ the domestic nominal money stock,

$\mathrm{P}=$ the domestic price level,

$\{\mathbf{M} / \mathbf{P}\}=$ the domestic real money stock,

$y=$ a measure of domestic real income or wealth,

$\mathbf{R}=\mathbf{a}$ domestic nominal interest rate 


$$
\begin{aligned}
& \hat{\mathrm{E}}= \text { the expected return from holding foreign } \\
& \text { money balances, and } \\
& \ln =\text { the natural logarithm. }
\end{aligned}
$$

We measure the expected return from holding foreign money balances with the expected rate of appreciation/depreciation of the exchange rate as approximated by the three-month forward premium/discount.

(2) $\hat{\mathrm{E}}^{*}=\left[(\mathrm{F} / \mathrm{S})^{4}-1\right] \times 100$,

where $\mathrm{F}$ is the three-month forward exchange rate between a specific foreign currency and the U.S. dollar; and $S$ is the spot icurrent exchange rate between the same two currencies.

Equation 1 allows for a relatively broad test of the currency substitution hypothesis. If domestic residents consider foreign currency balances and foreigncurrency-denominated, interest-earning assets (for example, Eurocurrency assets to be substitutes, the domestic interest rate variable $(\boldsymbol{R})$ in equation 1 will capture this behavior; the relatively uninhibited international mobility of capital requires that interest rates worldwide ladjusted for expected exchange rate changes/ be equal. Consequently, foreign interest rate changes not totally compensated for by expected changes in the exchange rate will produce concomitant movements in domestic interest rates and, subsequently, the normal money demand response.

On the other hand, if people are holding noninterest-earning foreign money balances for whatever pupose (transactions or speculative), the expected change in the exchange rate represents the opportunity cost of holding these foreign balances. Testing for this type of currency substitution requires determining whether the addition of $\hat{E}^{*}$ to a standard domestic money demand equation significantly improves the explanatory power of the equation. For currency substitution to have an impact, the estimated coefficient on $\hat{E}^{*}$ should be statistically significant and negative; as the expected return from holding foreign money balances rises, other things equal, individuals will hold relatively smaller domestic real money balances. If these two conditions are not met, the currency substitution hypothesis will have been rejected by the statistical tests.

\footnotetext{
${ }^{10}$ This specification is taken from Bordo and Choudhri (1982). For other studies employing the money demand function as the tool of analysis, see Cuddington (1983), Daniel and Fried (1983) and Spinellit.
}

\section{Empirical Results}

We investigate the existence of currency substitution in five countries: Canada, France, Germany, the Netherlands and the United Kingdom. ${ }^{11}$ In each instance, the U.S. dollat is assumed to be the foreign currency that substitutes for the relevant domestic currency. ${ }^{12}$ The data used are quarterly observations and are seasonally adjusted at the source. For each country, the income measure is real GNP or real GDP, depending on availability; the price level is measured by the relevant GNP or GDP deflator; and the interest rate is a shortterm one. ${ }^{13}$ The money stock used is always the narrowly defined aggregate (M1), enabling us to focus on the possible impact of currency substitution on the ability to control the money stock held for transaction purposes - the measure most closely associated with changes in economic activity. ${ }^{14}$

Because the sample periods extend back to the mid1960 s, estimating equation 1 without regard to the possible effects of the change in exchange rate regimes that occurred in the early 1970 s would cloud the interpretation of the $\hat{\mathbf{E}}^{*}$ variable. To circumvent this problem without reducing the number of observations, we estimate the effects of currency substitution using $(0,1)$ interactive terms to separate the fixed and flexible exchange rate periods. Thus, $\hat{\mathbf{E}} 1$ equals the value of $\hat{\mathbf{E}}^{*}$ for the fixed exchange rate period and zero elsewhere; $\hat{\mathrm{E}} 2$ equals the value of $\hat{\mathrm{E}}^{*}$ for the flexible exchange rate period and zero elsewhere. In this manner, the differential effects of currency substitution, if they exist, can be contrasted under the two exchange rate regimes.

Estimates of equation 1 first were obtained excluding $\hat{\mathrm{E}}^{*}$ as an explanatory variable. The individual country estimates (and their respective sample periods) are

\footnotetext{
${ }^{11}$ Cuddington also has investigated this issue for several countries. Untortunately, he fails to recognize changes in exchange rate regimes and their possible effects on the estimated parameters.

12 Tests also were conducted using the German DM forward premium to calculate $\hat{E}^{\star}$. These results are consistent with those reported in the paper.

${ }^{13}$ The countries using GNP are Canada, Germany and the Netherlands. GDP is used for France and the United Kingdom. The interest rates used are: the three-month interbank deposit rate for Germany, the Netherlands and the United Kingdom; the three-month prime finance company paper rate for Canada; and the three-month interbank money rate against private paper for France.

${ }^{14} \mathrm{For}$ an analysis of the relationship between $\mathrm{Mt}$ and economic activity in the countries examined here (excluding the Nethetlands). see Batten and Hafer (1983).
} 


\section{Table 1}

\section{Standard Money Demand Estimation}

\begin{tabular}{|c|c|c|c|c|c|c|c|}
\hline country sample pgroe & Constant & \% & $7(5+10)$ & $\left(W P T^{2}\right.$ & F? & $S E$ & $\pi(0)$ \\
\hline 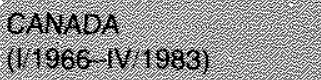 & $\begin{array}{l}0.026 \\
(0.49)\end{array}$ & $(2.63)$ & $(5.621$ & 10.0 .984 & 6971 & 00165 & 65 \\
\hline 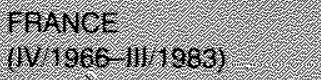 & $\left(\begin{array}{l}17.9 \\
(2.19)\end{array}\right.$ & $\begin{array}{l}(1081 \\
(280)\end{array}$ & $\begin{array}{l}0.200 \\
12.161\end{array}$ & $(10.19)$ & 6897 & 0.0196 & 0.94 \\
\hline Genviat) & $(4,111)$ & $(1,76)$ & $(0.449$ & $(33.685$ & 1067 & 0.0094 & 021 \\
\hline 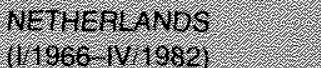 & $(0,043)$ & 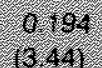 & $(1056$ & $(177)^{3}$ & 0.68 & 0.0167 & 6.44 \\
\hline 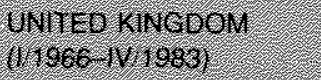 & 61028 & $\frac{0.057}{1.61}$ & $(6.05)$ & $(27.939$ & 0.61 & 0.0192 & 6 \\
\hline
\end{tabular}

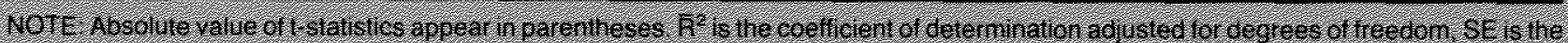

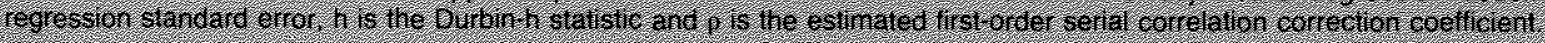

presented in table $1 . .^{15}$ The estimated coefficients generally have the theoretically expected sign and are significant at acceptable statistical levels. The overall explanatory power of each equation is quite high; the $\overline{\mathrm{R}}^{2}$ s indicate that the right-hand-side variables explain at least 90 percent of the variance of real money holdings. Moreover, except for the Netherlands, the Durbin h-statistics indicate that the ordinary least squares estimates are not plagued by first-order autocorrelation. In the case of the Netherlands, a first -order correction adequately solves the problem.

With respect to available money demand estimates, the estimated coefficients in table 1 seem quite reasonable. ${ }^{13}$ For instance, the estimated average speed of adjustment of actual real balances to desired $\left(1-\hat{\beta}_{4}\right)$ is about 15 percent per quarter. The average long-run income elasticity $\left(\hat{\beta}_{1} /\left(1-\hat{\beta}_{4}\right)\right)$ is estimated to be 0.76 , with only the German estimate $(1,20)$ appearing out of line. The interest elasticities also appear reasonable; the average short-run elasticity is -0.034 , although there is a wide range of point estimates.

To examine the extent of currency substitution, the variables $\hat{E} 1$ and $\hat{E} 2$ are added to the equations in table 1: these results are presented in table 2. As indicated earlier, if currency substitution between a particular

\footnotetext{
${ }^{15}$ Following Bordo and Choudhri, the domestic interest rate and the expected change in the exchange rate variables are estimated in nonlogarithmic form.

${ }^{16}$ See Boughton (1981) and references therein.
}

foreign currency and the U.S. dollar is relevant, the estimated coefficients on these variables should be negative and statistically significant. The results in table 2, however, indicate that there is little statistical support for currency substitution in our sample of countries. The estimated coefficients on the $\hat{E}^{*}$ terms generally are not statistically significant. Moreover, the estimated parameters do not always have the predicted negative sign. ${ }^{\mathrm{t}}$

Only for Canada and Germany during the flexible exchange rate period is there a statistically significant (at the 5 percent level) effect. ${ }^{18}$ Although the effect is

\footnotetext{
${ }^{17}$ We tested for the impact that exchange controls in the United Kingdom may have had on the reported resuits. Our evidence indicated that accounting for these controls and their abolition in 1979 did not alter the results reported in the text. Furthermore, we also estimated the set of equations using a seemingly unrelated regression procedure. These results were not qualitatively different from those presented.

${ }^{18}$ The Canadian result is contrary to that found by Bordo and Choudhri, and Cuddington. The difference in the results stems from the different sample periods used: Bordo and Choudhri, and Cuddington both ended their sample period in 1979, whereas our sample extends into 1983 . When we estimated our equations through 1979, we also found no statistical effect of currency substitution: the estimated coefficient on $\hat{E} 2$ is $-0.202\left(\times 10^{-2}\right)$ with a t-statistic of -1.50 . Adding the post-1979 observations provides the statistical significance of the $E 2$ variable, because the variance of the $E_{2}$ variabie during the post-1979 period is much larger than before. For instance, the mean value of the absolute change in the forward premium is 0.83 for the period IIV/1970 to IV/1979. The variance during this period is 0.32 . In contrast, from $1 / 1980$ to IV/1983, the mean value increases sharply to 1.30 , and the variance also rises to 1.47. Thus, the statistical significance in our study reative to eartier works results from including more recent data.
} 


\section{Table 2}

\section{Money Demand Estimates Using U.S. Forward Premium}

\begin{tabular}{|c|c|c|c|c|c|c|c|c|c|}
\hline Covir lsample perlod & constan & 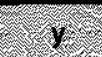 & $\mathrm{p}(\mathrm{x}, 10 \mathrm{~T})$ & $(1,1 \times 10$ & $(-2)(10)$ & (MI) & h & $\mathrm{se}$ & 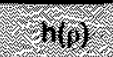 \\
\hline 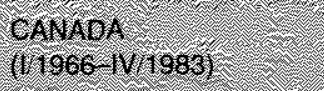 & .0041 & $(2085)$ & 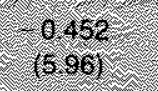 & $\begin{array}{r}0,018 \\
(0,04)\end{array}$ & $(206)$ & $\begin{array}{r}0932 \\
(34,50)\end{array}$ & 0.97 & 0.0 .62 & 12 \\
\hline 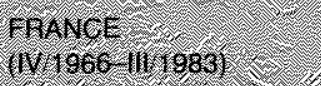 & $(0,796$ & $(2.06)$ & $\begin{array}{l}0.205 \\
(2,15)\end{array}$ & $(0,0)$ & $\frac{.6206}{(0.73)}$ & 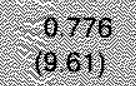 & 0.005 & 0.6198 & \\
\hline (1) & $(3.56$ & $\left(\begin{array}{l}0.161 \\
(5.23)\end{array}\right.$ & $(10,49)$ & 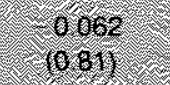 & 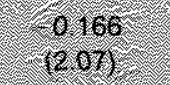 & $\left(26,077^{2}\right.$ & 6.997 & 0.0692 & 033 \\
\hline 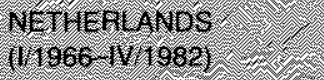 & 9010 & $(299)$ & $\begin{array}{r}0.276 \\
(2.96)\end{array}$ & $(1.290$ & $(1,26$ & $\begin{array}{r}0.753 \\
(1032)\end{array}$ & 1986 & 0.0166 & $\begin{array}{l}0,41 \\
0.67\end{array}$ \\
\hline 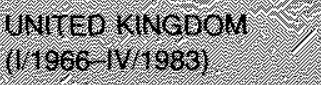 & $(9,267$ & $\begin{array}{l}0.072 \\
1694\end{array}$ & $(5.638$ & $\frac{6}{6.36}$ & 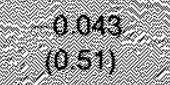 & $(1,5,929$ & a. 60 & 1019 & 0.98 \\
\hline
\end{tabular}

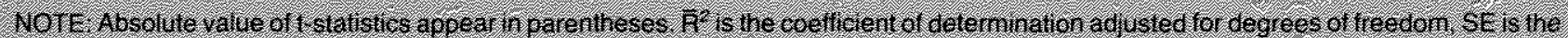

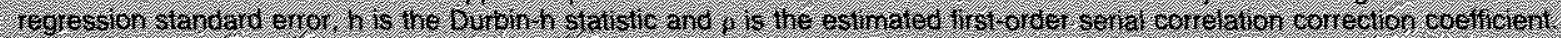

statistically significant, the economic significance of cumency substitution for each country is quite small. For example, a 1 percent increase in the forward premium/discount $\left(\hat{\mathrm{E}}^{*}\right)$ during the flexible-rate period induces Canadians to lower their holdings of Canadian real money balances by only 0.0007 percent, on aver" age. Furthermore, since the largest quarterly change in $\hat{\mathrm{E}}^{*}$ during the flexible exchange rate period was 4 percentage points, the largest quarterly change in Canadian real money holdings motivated by a change in the expected appreciation/depreciation of the U.S. dollar was 0.012 percent ${ }^{19}$ Likewise, a 1 percent increase in $\hat{\mathrm{E}}^{*}$ for Germany during the flexible-rate period induces a 0.003 percent decline in real monev holdings, on average, and the largest quarterly change in real money holdings caused by a change in $\hat{\mathrm{E}}^{*}$ was 0.015 percent.

\section{SUMMARY AND CONCLUSION}

Theoretical discussions suggest that the presence of currency substitution may defeat the policy-insulating properties of a flexible exchange rate regime. Under a system of fixed exchange rates, monetary authorities must maintain the exchange rate within some fixed range. Consequently, policy actions taken by a foreign

\footnotetext{
${ }^{19}$ The economic significance of currency substitution also is questioned by Laney, Radcliffe and Willett (1984). Based on estimates for the United States, they find that a too basis-point increase in the foreign opportunity cost of holding domestic dollas balances reduces holdings of domestic currency by only 0.025 percent. It should be noted, however, that the model from which this estimate is derived (based on Miles (1978a)) has been criticized by Bordo and Choudhri, and Spinelfi.
}

central bank that upset the prescribed exchange rate between domestic and foreign money require domestic monetary authorities to increase or decrease their money stock to stabilize the exchange rate. Under a flexible exchange regime, however, the rate is allowed to move with market forces. In this way, prices mat is, the exchange rate - adjust to clear the market for currencies without the need for intervention.

In a world of flexible exchange rates with currency substitution, policy responses may regress to those more common to a fixed exchange rate regime. This is because domestic holdings of money are influenced by changes in the opportunity costs of holding domestic and foreign currencies. When the possible impact of such currency substitution was subjected to empirical investigation, it generally was found to be statistically insignificant. In the two countries /Canada and Germany) where currency substitution was found to have a statistically significant effect, the magnitude of the effect on real money holdings was minimal. Thus, contrary to recent arguments, it does not appear that currency substitution significantly compromises monetary independence in a system of flexible exchange rates.

\section{REFERENGES}

Batten, Dallas S., and R. W. Hafer. "The Relative Impact of Monetary and Fiscal Actions on Economic Activity: A Cross-Country Comparison," this Review (January 1983), pp. 5-12.

Batten, Dallas S., and Mack Ott. "Five Common Myths About Floating Exchange Rates," this Review (November 1983), pp. 5-15.

"What Can Central Banks Do About the Value of the Dollar?" this Review (May 1984), pp. 16-26. 
Bordo, Michael D., and Ehsan U. Choudhri. "Currency Substitution and the Demand for Money: Some Evidence for Canada," Journal of Money, Credit and Banking (February 1982), pp. 48-57

Boughton, James $M$. "Recent Instability of the Demand for Money: An International Perspective, "Southern Economic Journal (January 1981), pp. 579-97.

Boyer, Russel S. "Currency Mobility and Balance of Payments Adjustment," in Biuford H. Putnam and D. Sykes Wiltord, eds., The Monetary Approach to international Adjustment (Praeger, 1978). pp. 184-98

Chrystal, K. Alec. "Demand for International Media of Exchange," American Economic Review (December 1977), pp. 840-50.

Chrystal, K. Alec, Nigel D. Wilson, and Philip Quinn. "Demand for International Money 1962-1977," European Economic Review (May 1983), pp. $287-98$.

Cuddington, John T. "Currency Substitution, Capital Mobility and Money Demand," Journal of international Money and Finance (August 1983), pp. 111-33.

Daniel, Betty C., and Harold O. Fried. "Currency Substitution, Postal Strikes, and Canadian Money Demand," Canadian Journal of Eco. nomics (November 1983), pp. 612-24.

Dornbusch, Rudiger. "Expectations and Exchange Rate Dynamics," Journal of Political Economy (December 1976), pp. 1161 76
Friedman, Milton. "The Case for Flexible Exchange Rates," in Milton Friedman, ed., Essays in Positive Economics (University of Chicago Press, 1953), pp. 157-203.

Laney, Leroy O., Chris D. Radcliffe, and Thomas D. Willett. "Currency Substitution: Comment," Southern Economic Joumal (April 1984), pp. 1196-200.

McKinnon, Ronald f. "Currency Substitution and Instability in the World Dollar Standard," American Economic Review (June 1982), pp. 320-33.

Miles, Marc A. "Currency Substitution, Flexible Exchange Rates, and Monetary Independence," American Economic Review (June 1978a), pp. 428-36.

"Currency Substitution: Perspective, Implications, and Empirical Evidence, ${ }^{t}$ in Putnam and Wilford, eds., The Monetary Approach to international Adjustment (Praeger, 1978b), pp. 17083.

"Currency Substitution: Reply," Southern Economic Journal (April 1984), pp. 1201-03.

Spinelli, Franco. "Currency Subsititution, Flexible Exchange Rates, and the Case for International Monetary Cooperation," IMF Staff Papers (December 1983), pp. 755-83

Tower, Edward, and Thomas D. Willett. The Theory of Optimum Currency Areas and Exchange-Rate Flexibility (International Fi. nance Section, Princeton University, 1976). 